Article

\title{
Farmland Rental and Productivity of Wheat and Maize: An Empirical Study in Gansu, China
}

\author{
Ying Liu ${ }^{1,2}$, Chenggang Wang ${ }^{3}$, Zeng Tang ${ }^{1,2}$ and Zhibiao Nan ${ }^{1,2, *}$ \\ 1 College of Pastoral Agricultural Science and Technology, Lanzhou University, Lanzhou 730020, China; \\ yliu13@lzu.edu.cn (Y.L.); tangz@lzu.edu.cn (Z.T.) \\ 2 State Key Laboratory of Grassland Agro-ecosystems, Lanzhou University, Lanzhou 730020, China \\ 3 Department of Agricultural and Applied Economics, Texas Tech University, Lubbock, TX 79409, USA; \\ chenggang.wang@ttu.edu \\ * Correspondence: zhibiao@lzu.edu.cn
}

Received: 12 August 2017; Accepted: 19 September 2017; Published: 21 September 2017

\begin{abstract}
The rapid growth of farmland rental markets in China raises questions about the association of farmland rental and agricultural productivity. Although this issue has been extensively studied, the majority of studies have focused on yields and technical efficiency, with input use and cost efficiency receiving little attention. This study aimed to determine the statistical association of wheat and maize farmers' farmland rental behaviors (renting land, not renting land and renting out land) and input use, and the consequent association of farmers' farmland rental behaviors and cost efficiency. For this purpose, the linear regression model and stochastic frontier model were employed, based on a survey data of 419 wheat and maize farmers in 25 villages in five counties of Gansu Province, China. The study found that farmland rental enhanced productivity and sustainability of agriculture through transferring farmland from households with less productivity to those with high productivity, and it was also helpful to reducing the consumption of fertilizers and chemicals in agricultural production. The results suggest that replacing labor with machines is an important way to reduce production costs, and households specializing in agricultural production use more rational amounts of fertilizers and chemicals than those with low productivity. Thus, the machinery purchase policy in China should continue to give great benefit to farmers. In addition, the machinery purchase subsidization policy has achieved satisfactory results in China, and it could be a good reference for other developing countries. However, some efficiency loss was found in households that rented out their land, and policy makers need to pay some attention to these households.
\end{abstract}

Keywords: farmland rental; land consolidation; input costs; cost efficiency; stochastic frontier model

\section{Introduction}

The proportion of the world's people that is hungry has dramatically decreased due to the marked growth in food production in the past half century [1]. Nevertheless, growing population and limited arable land continue to challenge food security [2]. The global population will continue to grow to more than nine billion by 2050, and crop production should be doubled to keep pace with the demands for food due to population growth [3,4]. How to expand agricultural output without greatly increasing the amount of land and other input use becomes the key issue to ensure food security [3].

China is the largest developing country with the largest population in the world $[5,6]$. Over the past several decades, China has successfully created the "Miracle in China" by feeding $22 \%$ of the global human population with less than $9 \%$ of the world's arable land, indicating a substantial contribution to global food security [7,8]. The "Miracle in China" can be attributed to the gains in agricultural productivity obtained through agricultural reform initiated in the late 1970s, which converted collective farming to a household responsibility system $[9,10]$. The change in land tenure greatly stimulated the 
enthusiasm of farmers and it has resulted in a huge growth in agricultural productivity since the late 1970s [11,12].

However, it is also worth noting that more than half of the increased crop production in China was based on a rapid increase in the consumption of fertilizers and chemicals $[8,13]$. Excessive fertilization in grain crop production has caused low nutrient use efficiency and high environmental costs $[14,15]$. On the other hand, as economic development has progressed in China, the contribution of agriculture to economy has declined from $40 \%$ in 1970 to less than $10 \%$ in 2013, along with a tremendous net loss of the productive agricultural labor force $[16,17]$. China's agricultural development is facing many new challenges, including the huge gap between lower-priced imported agricultural products and higher-priced domestically produced agricultural products, aging farmers, declining land area, and deteriorating ecological environment [18].

To address these challenges, the Chinese Government is promoting the formation of large-scale and mechanized farms $[18,19]$. In fact, in the Chinese Number 1 Document of 1984, the central government encouraged large-scale farming by promoting the development of farmland rental markets. Farmland rental and large-scale farming were further emphasized in the Chinese Number 1 Document of 2012 to 2017. Furthermore, to promote farmland rental and large-scale farming, a series of agricultural policies was launched, including farmland certification, subsidies on leased land, farmland collateral, and agricultural insurance [20]. In addition, the booming off-farm labor markets have also accelerated the development of farmland rental markets [21-23]. China's farmland rental policy gained rapid support, while only $5.2 \%$ of contracted farmland was leased in $2007,33.3 \%$ had been leased by the end of 2015 [24,25].

The issues related to farmland rental in China have received special attention by economists and policy makers, and many studies have focused on the understanding of the determinants of farmland rental. Some studies found that off-farm employment and migration had critical positive impacts on farmland renting-out behavior of rural households [22,26,27]. Not only did availability of off-farm employment significantly improve farmland rental, but tenure security and agricultural ability also played a critical role in farmland rental [28,29]. In addition, the impacts of credit market development, productive heterogeneity among farmers, institutional building, contract conditions, property rights, household attributes, and institutional building on farmland rental market were extensively studied $[23,30]$. Some studies explored the influences of farmland rental and consolidation. For instance, a series of studies focused on the impacts of farmland rental and consolidation on agricultural efficiency and productivity, agricultural investments to land of rural households, occupational diversification, income inequality and household welfare [9,19,31-33].

Theoretically, land consolidation via farmland rental can enhance agricultural productivity by equalizing the marginal product of land among households with different labor endowments and by facilitating transfers of farmland from less productive households to more productive ones [12,34]. A number of studies approved the positive impacts of farmland rental on agricultural productivity. Feng [12] indicated that households renting land achieved higher technical efficiency than those not renting land. Jin and Deininger [32] found farmland rental markets were critical not only for non-agricultural growth, but they also contributed to significant productivity gains by allowing more effective use of potentially idle land. A plot-level study also showed households renting extra land were relatively more productive than those not renting land [21]. The study by Lohmar et al. [35] suggested that farmland rental increased aggregate agricultural production by transferring land from low intensity farm households to households willing to farm the land more intensively. Besides, Wang et al. [36] used the method of Propensity Score Matching to analyze impacts of farmland rental on labor productivity and found that farmland rental had a positive effect on total labor productivity and agricultural labor productivity, especially in plain areas. However, some research found a negative effect of farmland rental and consolidation on agricultural production. The study by Reda et al. [19] indicated that grain yield declined with farmland consolidation. Gao et al. [33] found that farmland rental contributed to the falling rates of investment in organic manure, and it might have negative 
impacts on agricultural productivity. A study on China and India showed a positive relationship between plot size and land yields in China, while a negative relationship between plot size and agricultural productivity in India [17].

These results dealing with impacts of farmland rental and consolidation on farm productivity of developing countries provide important hints to understand how farmland rental influences agriculture productivity, but they mainly focused on crop yield and technical efficiency [12,17,19,37-39]. Unfortunately, high crop yields may be at the cost of high labor, fertilizer and chemical consumption. Technical efficiency represents only a part of agricultural productivity, since it is an indicator to determine whether households use the latest production technologies, without taking the effects of resource allocation into account. Thus, crop yield and technical efficiency only reflect a part of agricultural productivity. Cost efficiency estimates the distance of observed cost to minimized cost with certain input prices and output levels. Since grain prices are stable in China, cost efficiency embodies the results of technical and allocative efficiency in grain production and thus it is a good indicator of grain productivity. However, few researchers have paid attention to the association of farmland rental and input use, as well as cost efficiency of agricultural production. As the new strategy of China is to boost productive capacity through the promotion of farmland rental and consolidation, it is important to examine this association.

The goal of this study is to assess farmland rental, particularly the relationship between farmland rental and input use, and the relationship of farmland rental and cost efficiency of grain production. Wheat and maize were chosen in this study, since they are the two main grain crops in rural areas of northwestern China, which take up $39.83 \%$ of the total planted area in the study area. Our analysis was based on a survey conducted in 2015 covering 419 households planting these two main crops in Gansu Province. We first used linear regression models to estimate the statistical association of rural households' farmland rental behaviors and costs per unit outputs of various inputs. Then, stochastic frontier models were used to estimate the statistical association of households' farmland rental behaviors and cost efficiency of wheat and maize production. We found that farmland rental can indeed enhance cost efficiency by the reallocation of farmland from less productive households to more productive households, and this is supported by the study of Feng [12] through estimating technical efficiency.

The remainder of the paper is organized as follows. Section 2 describes the data collection and samples. Section 3 presents the linear regression models and stochastic frontier models applied to the study, and variable descriptions. Section 4 reports the results. The conclusions and policy implications are offered in the final section.

\section{Data Collection and Samples}

The data for this study were derived from a survey of rural households conducted in selected 25 townships in five counties of Gansu Province, China (Figure 1). Gansu Province is located in the upstream of Yellow River Basin, which is the junction of Inner Mongolian Plateau, Loess Plateau and Qinghai-Tibet Plateau. Gansu Province represents a grain production area in arid and semiarid climate. It has a land area of about $4.7 \%$ of the total area of China and is one of the major grain producing provinces in northwestern China, with a planted grain crops area of about $2.5 \%$ of national level during 2015, which is larger than that in most of the provinces in northwestern China [40]. Gansu Province is one of the less developed regions of China with relatively poor agricultural production conditions and low level of urbanization, and farmland rental in Gansu Province has proceeded rapidly. For example, $10.4 \%$ of contracted farmland had been leased in September 2012, while $18 \%$ of contracted farmland had been leased in September 2014 [41,42]. Thus, the study of Gansu Province may provide some hints for not only northwestern China, but also some areas similar with Gansu in other countries. 


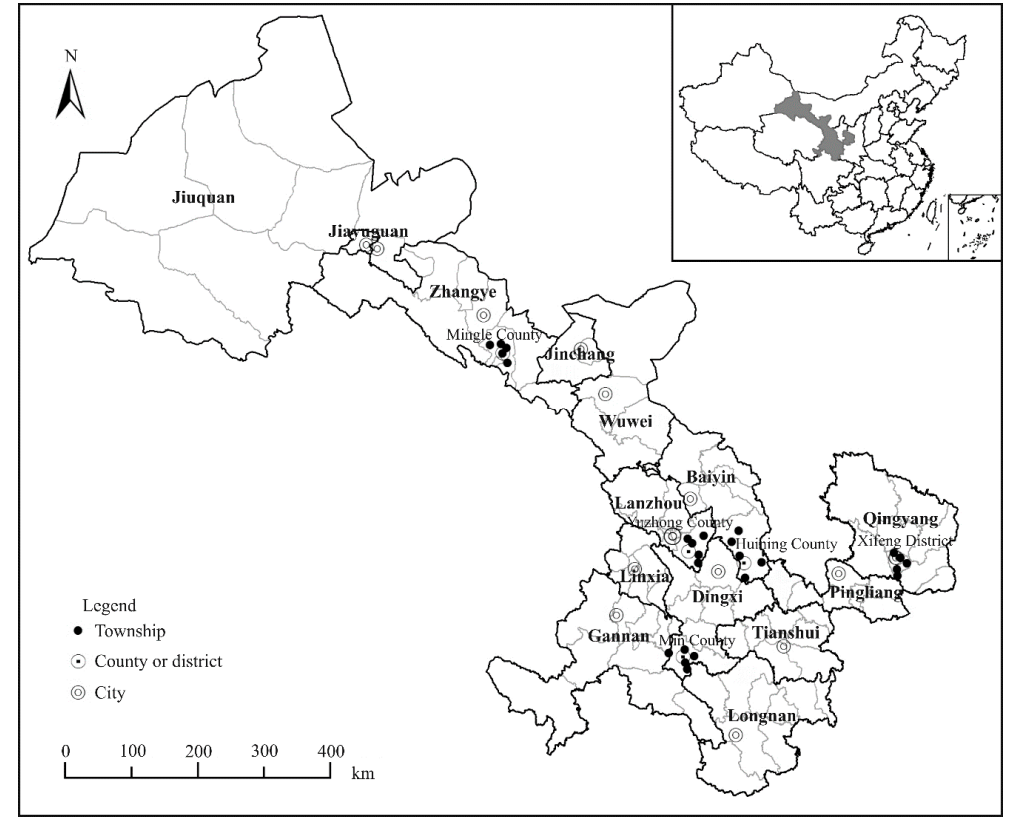

Figure 1. Study area and sample distribution.

The survey was conducted from April to September 2015. Five counties were selected using the sampling methods of Huang et al. [22]. Specifically, all 86 counties or districts in Gansu Province were sorted from high to low by the average total industry output value per capita in 2012, which is an indicator of the level of economic development. The counties were then divided into five groups, and a county district was randomly chosen from each group to represent that group. Within each county, five townships were randomly chosen, generating totally 25 townships in the sample. The five selected counties were Xifeng district, Yuzhong county, Mingle county, Huining county and Ming county, which represent the majority of farmland types and planting models in Gansu Province (Figure 1). For example, Mingle county represents Hexi Corridor, and Huining county represents Loess Plateau. Their average total industry output value per capita in 2012 was 23691 Yuan, 8656 Yuan, 4453 Yuan, 1447 Yuan and 778 Yuan, respectively (Table 1). Furthermore, one village was randomly selected from each township, yielding 25 villages in the sample (Figure 1). Finally, we interviewed 20 to 30 rural households from each village, and the survey was conducted with the household head. Totally, 705 households were surveyed. The interview was conducted by students of Lanzhou University with proper training. They were randomly dropped off in the front door of a household to conduct the interview. The questionnaire contains demographic information, planting and breeding situation, inputs and outputs of crops, farmland types and area, farmland rental situations in 2014, and willingness to rent or rent out farmland. After excluding the households that did not grow wheat or maize from the sample, we were left with a sample of 419 households for the ensuing analysis.

Table 1. Sample structure.

\begin{tabular}{ccccccc}
\hline Items & Xifeng & Yuzhong & Mingle & Huining & Ming & Total \\
\hline Average industrial output value per capita & 23,691 & 8656 & 4453 & 1447 & 778 & -- \\
Group & 1 & 2 & 3 & 4 & 5 & -- \\
Number of households in survey & 144 & 157 & 123 & 132 & 149 & 705 \\
Number of households in wheat analysis & 109 & 52 & 61 & 75 & 25 & 322 \\
Number of households in maize analysis & 95 & 73 & 31 & 122 & 0 & 321 \\
Number of households included in analysis & 127 & 83 & 61 & 123 & 25 & 419 \\
\hline
\end{tabular}

Note: Average industrial output value per capita is from the data of 2012 (the resource is Gansu Development Yearbook 2013), and measured in Yuan; Total is the sum of five counties; - - indicates not applicable. 
Table 2 presents farmland rental situations of wheat and maize farmers at the county level. The number of wheat farmers who were renting land, not renting land and renting out land was 50 , 233 and 39, respectively, and the percentage was $15.33 \%, 72.36 \%$ and $12.11 \%$, respectively. For the maize analysis, the number of farmers who were renting land, not renting land and renting out land was 48,235 and 38 , respectively, and the percentage was $14.95 \%, 73.21 \%$ and $11.84 \%$, respectively. Farmland rental market in Gansu Province was still at its infancy in 2014.

Table 2. Summary statistics on the situations of farmland rental in study area.

\begin{tabular}{|c|c|c|c|c|c|c|}
\hline \multirow[b]{2}{*}{ Counties } & \multicolumn{2}{|c|}{ Renting Land } & \multicolumn{2}{|c|}{ Not Renting Land } & \multicolumn{2}{|c|}{ Renting out Land } \\
\hline & $\begin{array}{l}\text { Number of } \\
\text { Households }\end{array}$ & Ratio (\%) & $\begin{array}{l}\text { Number of } \\
\text { Households }\end{array}$ & Ratio (\%) & $\begin{array}{l}\text { Number of } \\
\text { Households }\end{array}$ & Ratio (\%) \\
\hline \multicolumn{7}{|c|}{ Wheat analysis } \\
\hline Xifeng & 5 & 4.59 & 81 & 74.31 & 23 & 21.10 \\
\hline Yuzhong & 6 & 11.54 & 42 & 80.77 & 4 & 7.69 \\
\hline Mingle & 18 & 29.51 & 34 & 55.74 & 9 & 14.75 \\
\hline Huining & 16 & 21.33 & 57 & 76.00 & 2 & 2.67 \\
\hline Ming & 5 & 20.00 & 19 & 76.00 & 1 & 4.00 \\
\hline Total & 50 & 15.53 & 233 & 72.36 & 39 & 12.11 \\
\hline \multicolumn{7}{|c|}{ Maize analysis } \\
\hline Xifeng & 6 & 6.32 & 67 & 70.53 & 22 & 23.16 \\
\hline Yuzhong & 8 & 10.96 & 58 & 79.45 & 7 & 9.59 \\
\hline Mingle & 11 & 35.48 & 16 & 51.61 & 4 & 12.90 \\
\hline Huining & 23 & 18.85 & 94 & 77.05 & 5 & 4.10 \\
\hline Ming & 0 & - - & 0 & - & 0 & - - \\
\hline Total & 48 & 14.95 & 235 & 73.21 & 38 & 11.84 \\
\hline
\end{tabular}

Note: Total is the sum of five counties; - - indicates not applicable.

Table 3 reports some descriptive information of study area. The average family size of rural households in study area was 4.62. The low average per capita annual income $\left(11.70 \times 10^{3}\right.$ Yuan $)$ indicated the poverty status of northwestern China. The average per capita land area was $2.60 \mathrm{mu}$, and the average planted area of wheat and maize was $2.20 \mathrm{mu}$ and $1.90 \mathrm{mu}$, respectively. The average price of wheat and maize was $2.37 \mathrm{Yuan} \cdot \mathrm{kg}^{-1}$ and $2.03 \mathrm{Yuan} \cdot \mathrm{kg}^{-1}$, respectively. Besides, the study

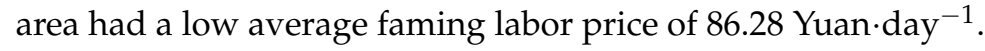

Table 3. Descriptive information of study area.

\begin{tabular}{cccccc}
\hline Items & Mean & SD & Min. & Max. & Observations \\
\hline Family size & 4.62 & 1.54 & 1 & 10 & 705 \\
Per capita annual income $\left(\times 10^{3}\right.$ Yuan) & 11.70 & 9.73 & 0.20 & 101.00 & 705 \\
Per capita land area $(\mathrm{mu})$ & 2.60 & 2.28 & 0.06 & 16.50 & 705 \\
Planted wheat area $(\mathrm{mu})$ & 2.20 & 11.68 & 0.00 & 300.00 & 705 \\
Planted maize area $(\mathrm{mu})$ & 1.90 & 3.27 & 0.00 & 50.00 & 705 \\
Price of wheat (Yuan $\left.\cdot \mathrm{kg}^{-1}\right)$ & 2.37 & 0.34 & 1.60 & 3.20 & 705 \\
Price of maize (Yuan $\left.\cdot \mathrm{kg}^{-1}\right)$ & 2.03 & 0.18 & 1.20 & 5.00 & 705 \\
Price of farming labor $\left(\right.$ Yuan $\cdot$ day $^{-1}$ ) & 86.28 & 20.92 & 40.00 & 190.00 & 705 \\
\hline
\end{tabular}

Note: Family size is measured by the number of family members; per capita land is defined as the per capita land owned by households; the price of wheat and maize is the selling price of wheat and maize in 2014; $1 \mathrm{mu}$ is $1 / 15$ hectare.

\section{Econometric Model and Variable Description}

\subsection{Models for Costs Estimation and Variable Description}

To estimate the statistical association of farmland rental and the production costs of wheat and maize, a linear regression model was used:

$$
Y_{i}=\alpha_{0}+\alpha_{1} R I_{i}+\alpha_{2} R O_{i}+X_{i}^{\prime} \beta+D_{i}^{\prime} \mu+\omega_{i}
$$


where $Y_{i}$ represents the dependent variable, and it can be various input costs (land cost, labor cost, machine cost, seed cost, water cost, fertilizer cost, chemical cost and total cost) per unit output, or output per unit area (for example, $Y_{i}$ is the labor cost per unit output when estimating the statistical association of farmland transfer and labor cost per unit output); $R I_{i}$ and $R O_{i}$ are binary indicators for renting farmland and renting out farmland behaviors of rural household $i$, respectively; $X_{i}^{\prime}$ is the vector of exogenous variables, including head age, education, agricultural labor, block size, soil fertility, landform; $D_{i}^{\prime}$ is a vector of dummies to partially take into account the heterogeneity of features in different counties, including Xifeng, Yuzhong, Mingle and Huining; $\alpha_{0}, \alpha_{1}, \alpha_{2}, \beta$ and $\mu$ are parameters to be estimated; and $\omega_{i}$ is the random disturbance term. The machine cost can be decomposed in to two parts:

$$
M E C_{i}=O M C_{i}+R M C_{i}
$$

where $O M C_{i}$ is the cost of machine owned by households, and $R M C_{i}$ is the cost of rented machine. To calculate the annual cost of machine owned by households, the fixed-rate mortgage (FRM) equation was employed [43]:

$$
P M_{j}\left(1+\delta_{j}\right)^{T}-A M C_{j} \frac{\left(1+\delta_{j}\right)^{T}-1}{\delta_{j}}=0
$$

where $P M_{j}$ is the price of machine $j ; \delta$ is the annual profit of the year when rural household brought the machine; $T_{j}$ is the lifespan of the machine $j$ which is 10 years here, since the average lifespan of diesel engine is 10 years; and $A M C_{j}$ is the annual cost for the machine $j$. Thus, the annual cost for the machine $j$ is:

$$
A M C_{j}=\frac{P M_{j} \delta_{j}\left(1+\delta_{j}\right)^{T}}{\left(1+\delta_{j}\right)^{T}-1}
$$

Finally, we obtain the cost of machine owned by household $i$ :

$$
O M C_{i}=\frac{\sum_{j=1}^{m} A M C_{j}}{T P A_{i}}
$$

where $m$ is the number of agricultural machines owned by rural household $i$, and $T P A_{i}$ is the total planted area of rural household $i$ in 2014.

In Table 4, the descriptive statistic of variables in cost estimation is listed. With the expectation of high returns from wheat and maize farming, households in Gansu Province spent a significant amount of money on labor, machines, seeds, water, fertilizers, chemicals and other materials and services. The average total cost per unit output was $4.93 \mathrm{Yuan} \cdot \mathrm{kg}^{-1}$, ranging from $1.38 \mathrm{Yuan} \cdot \mathrm{kg}^{-1}$ to $25.48 \mathrm{Yuan} \cdot \mathrm{kg}^{-1}$ in the wheat analysis, and $2.84 \mathrm{Yuan} \cdot \mathrm{kg}^{-1}$, ranging from $0.97 \mathrm{Yuan} \cdot \mathrm{kg}^{-1}$ to $7.73 \mathrm{Yuan} \cdot \mathrm{kg}^{-1}$ in the maize analysis. The average output per mu of wheat was $286.13 \mathrm{~kg} \cdot \mathrm{mu}^{-1}$, ranging from $45.00 \mathrm{~kg} \cdot \mathrm{mu}^{-1}$ to $570.00 \mathrm{~kg} \cdot \mathrm{mu}^{-1}$, and the average output per mu of maize was $576.09 \mathrm{~kg} \cdot \mathrm{mu}^{-1}$, ranging from $220.00 \mathrm{~kg} \cdot \mathrm{mu}^{-1}$ to $970.00 \mathrm{~kg} \cdot \mathrm{mu}^{-1}$. The data suggest a significant variability in total cost per unit output and the output per unit area in wheat and maize production.

The key dependent variables are rural households' farmland rental behaviors, including renting land and renting out land. Besides, some farm-specific variables are also included: head age and education represent farmer characteristics; agricultural labor represents household characteristics; block size, soil fertility and land form represent farmland characteristics; Xifeng, Yuzhong, Mingle and Huining are area dummies (Table 4). 
Table 4. Statistic description of variables in cost estimation.

\begin{tabular}{|c|c|c|c|c|c|c|c|c|}
\hline \multirow{2}{*}{ Variables } & \multicolumn{4}{|c|}{ Wheat Analysis } & \multicolumn{4}{|c|}{ Maize Analysis } \\
\hline & Mean & SD & Min. & Max. & Mean & SD & Min. & Max. \\
\hline \multicolumn{9}{|c|}{ Dependent variables } \\
\hline Land cost & 0.89 & 0.43 & 0.08 & 3.68 & 0.41 & 0.28 & 0.05 & 1.45 \\
\hline Labor cost & 2.67 & 2.36 & 0.15 & 18.00 & 1.74 & 0.98 & 0.24 & 5.66 \\
\hline Machine cost & 0.54 & 0.46 & 0.00 & 3.00 & 0.16 & 0.17 & 0.00 & 1.31 \\
\hline Seed cost & 0.22 & 0.15 & 0.04 & 1.71 & 0.13 & 0.09 & 0.03 & 0.54 \\
\hline Water cost & 0.12 & 0.19 & 0.00 & 1.02 & 0.08 & 0.11 & 0.00 & 0.67 \\
\hline Fertilizer cost & 0.40 & 0.25 & 0.00 & 1.89 & 0.24 & 0.16 & 0.00 & 0.16 \\
\hline Chemical cost & 0.08 & 0.07 & 0.00 & 0.47 & 0.06 & 0.05 & 0.00 & 0.37 \\
\hline Total cost & 4.93 & 2.70 & 1.38 & 25.48 & 2.84 & 1.25 & 0.97 & 7.73 \\
\hline Output & 286.13 & 112.81 & 45.00 & 570.00 & 576.09 & 168.25 & 220.00 & 970.00 \\
\hline \multicolumn{9}{|c|}{ Independent variables } \\
\hline Renting land & 0.16 & 0.36 & 0 & 1 & 0.15 & 0.36 & 0 & 1 \\
\hline Renting out land & 0.12 & 0.33 & 0 & 1 & 0.12 & 0.32 & 0 & 1 \\
\hline Head age & 52.00 & 10.50 & 23 & 78 & 52.77 & 10.21 & 28 & 79 \\
\hline Education & 6.44 & 3.82 & 0.00 & 14.00 & 6.71 & 3.59 & 0.00 & 12.00 \\
\hline Agricultural labor & 0.35 & 0.24 & 0.00 & 1.00 & 0.35 & 0.24 & 0.00 & 1.00 \\
\hline Block size & 2.32 & 1.45 & 0.26 & 9.00 & 2.40 & 1.64 & 0.25 & 15.00 \\
\hline Soil fertility & 0.44 & 0.59 & -1 & 1 & 0.36 & 0.62 & -1 & 1 \\
\hline Landform & 0.44 & 0.50 & 0 & 1 & 0.42 & 0.49 & 0 & 1 \\
\hline Xifeng & 0.34 & 0.47 & 0 & 1 & 0.30 & 0.46 & 0 & 1 \\
\hline Yuzhong & 0.16 & 0.37 & 0 & 1 & 0.23 & 0.42 & 0 & 1 \\
\hline Mingle & 0.20 & 0.39 & 0 & 1 & 0.10 & 0.30 & 0 & 1 \\
\hline Huining & 0.23 & 0.42 & 0 & 1 & 0.38 & 0.49 & 0 & 1 \\
\hline
\end{tabular}

Note: $1 \mathrm{mu}$ is $1 / 15$ hectare; the cost of land is measured by average land rental price in a village; all costs are costs per unit output, and measured in Yuan $\cdot \mathrm{kg}^{-1}$; the total cost per unit output includes land cost and all other costs in production; output is the output per unit area, measured in $\mathrm{kg} \cdot \mathrm{mu}^{-1}$; education is the education year of household head; agricultural labor is the ratio of agricultural labor (defined as family members who are actually engaged in agricultural production, not in school and between 16 and 65 years old) [22] to family size; block size is the average block size of operating land (operating farmland $=$ own land plus rent-in and minus rent-out), measured in mu; soil fertility of operating land is defined as poor $=-1$, medium $=0$, good $=1$; landform of operating land is defined as 0 when farmland was located in sloping area, and 1 when farmland was located in flat area. The same below.

\subsection{Models for Cost Frontier Function and Cost Efficiency Estimation and Variable Description}

The Stochastic Frontier Analysis method (SFA) discussed by Coelli et al. [44] was employed to estimate the cost efficiency of wheat and maize production. To estimate the economic characteristics of production technology by given output and input prices, the cost frontier can be written in general from:

$$
C_{i} \geq C_{i}^{\prime}\left(Q_{i}, P N_{i}, P L_{i}, P M_{i}\right)
$$

where $C_{i}$ is the observed cost of household $i ; Q_{i}$ is output; $P N_{i}$ is price of land; $P L_{i}$ is price of labor; $P M_{i}$ is price of material; and $C_{i}^{\prime}$ is a cost function that is non-decreasing, linearly homogeneous and concave in prices. The Cobb-Douglas functional form was used to fit separate stochastic cost frontiers for wheat and maize using maximum likelihood procedures [45]. Despite its well-known limitations, the Cobb-Douglas was chosen because this functional form has been widely used in farm efficiency analyses for both developing and developed countries, and functional specification has rather small impact on estimated efficiency $[38,46]$. The relationship between cost and prices under certain output level for wheat and maize production can be represented as:

$$
\left\{\begin{array}{c}
C_{i} \geq \mathrm{e}^{\beta_{0}} Q_{i}^{\beta_{1}} P N_{i}^{\beta_{2}} P L_{i}^{\beta_{3}} P M_{i}^{\beta_{4}} \mathrm{e}^{v_{i}} \\
\text { st. } \beta_{2}+\beta_{3}+\beta_{4}=1
\end{array}\right.
$$


where $\beta_{0}, \beta_{1}, \beta_{2}, \beta_{3}$ and $\beta_{4}$ are parameters to be estimated; and $v_{i}$ is a symmetric random variable representing errors of approximation and other sources of statistical noise. Adding the term of inefficiency, the function can be rewritten as follow:

$$
\left\{\begin{array}{c}
C_{i}=\mathrm{e}^{\beta_{0}} Q_{i}^{\beta_{1}} P N_{i}^{\beta_{2}} P L_{i}^{\beta_{3}} P M_{i}^{\beta_{4}} \mathrm{e}^{v_{i}+u_{i}} \\
\text { st. } \beta_{2}+\beta_{3}+\beta_{4}=1
\end{array}\right.
$$

where $u_{i}$ is a non-negative variable representing inefficiency. Taking logarithm in both sides of Equation (8):

$$
\left\{\begin{array}{c}
\ln C_{i}=\beta_{0}+\beta_{1} \ln Q_{i}+\beta_{2} \ln P N_{i}+\beta_{3} \ln P L_{i}+\beta_{4} \ln P M_{i}+v_{i}+u_{i} \\
\text { st. } \beta_{2}+\beta_{3}+\beta_{4}=1
\end{array}\right.
$$

Substituting the constraint into equation:

$$
\ln \frac{C_{i}}{P M_{i}}=\beta_{0}+\beta_{1} \ln Q_{i}+\beta_{2} \ln \frac{P N_{i}}{P M_{i}}+\beta_{3} \ln \frac{P L_{i}}{P M_{i}}+v_{i}+u_{i}
$$

A measure of cost efficiency $\left(C E_{i}\right)$ is the ratio of minimum cost to observed cost, which can be shown as:

$$
C E_{i}=\frac{C_{i}^{\prime}}{C_{i}}=\frac{\mathrm{e}^{\beta_{0}} Q_{i}^{\beta_{1}} P N_{i}^{\beta_{2}} P L_{i}^{\beta_{3}} P M_{i}^{\beta_{4}} \mathrm{e}^{v_{i}}}{\mathrm{e}^{\beta_{0}} Q_{i}^{\beta_{1}} P N_{i}^{\beta_{2}} P L_{i}^{\beta_{3}} P M_{i}^{\beta_{4}} \mathrm{e}^{v_{i}+u_{i}}}=\mathrm{e}^{-u_{i}}
$$

To estimate the statistical association of rural households' farmland rental behaviors and cost efficiency of wheat and maize production, the inefficiency components were estimated by the method of Battese and Coelli [47]:

$$
\left\{\begin{array}{c}
\ln \frac{C_{i}}{P M_{i}}=\beta_{0}+\beta_{1} \ln Q_{i}+\beta_{2} \ln \frac{P N_{i}}{P M_{i}}+\beta_{3} \ln \frac{P L_{i}}{P M_{i}}+v_{i}+u_{i} \\
u_{i}=X_{i}^{\prime} \delta+D_{i}^{\prime} \varphi+\theta_{i}
\end{array}\right.
$$

where $X_{i}^{\prime}$ is a vector of exogenous variables associated with cost efficiency of wheat or maize production, including head age, education, agricultural labor, block size, soil fertility, landform, which is the same as defined in Equation (1); $D_{i}^{\prime}$ is a vector of dummies to partially take into account the heterogeneity of features in different counties, including Xifeng, Yuzhong, Mingle and Huining; $\delta$ and $\varphi$ are parameters to be estimated; and $\theta_{i}$ is a random variable defined by the truncation of the normal distribution with zero mean and variance $\sigma_{u}^{2}$, and $\theta_{i} \geq-X_{i}^{\prime} \delta$ for the assumption of $u_{i}$ being a non-negative truncation distribution of $\mathrm{N}\left(X_{i}^{\prime} \delta, \sigma_{u}^{2}\right)$.

Table 5 presents the statistic description of logarithm values of input and output variables in cost frontier and cost efficiency estimation, including the indicators of cost, output, price of land, price of labor and price of materials in wheat and maize production.

Table 5. Statistic description of input and output variables in cost frontier and cost efficiency estimation.

\begin{tabular}{ccccccccc}
\hline \multirow{2}{*}{ Variables } & \multicolumn{3}{c}{ Wheat Analysis } & \multicolumn{3}{c}{ Maize Analysis } \\
\cline { 2 - 8 } & Mean & SD & Min. & Max. & Mean & SD & Min. & Max. \\
\hline $\ln$ (Cost) & 8.20 & 0.60 & 6.44 & 12.65 & 8.48 & 0.60 & 5.28 & 10.84 \\
$\ln$ (Output) & 6.69 & 0.88 & 4.16 & 11.73 & 7.50 & 0.71 & 3.85 & 10.24 \\
$\ln$ (Price of land) & 5.33 & 0.59 & 3.79 & 6.24 & 5.13 & 0.82 & 3.79 & 6.42 \\
$\ln$ (Price of labor) & 4.46 & 0.22 & 3.69 & 5.25 & 4.47 & 0.19 & 4.09 & 5.25 \\
$\ln$ (Price of materials) & 0.10 & 0.00 & 0.10 & 0.10 & 0.10 & 0.00 & 0.10 & 0.10 \\
\hline
\end{tabular}

Note: Cost is the total cost including land cost, labor cost and material cost, and measured in Yuan; output is the total output of wheat or maize, measured in $\mathrm{kg}$; land price is the average farmland rental price at village level, measured in Yuan $\cdot \mathrm{mu}^{-1}$; labor price is measured in Yuan $\cdot \mathrm{day}^{-1}$; materials include seed, water, fertilizer, chemicals, mulch and other agricultural production materials and services, and their price is measured in Yuan, using a price of 1.1 implies a cost of operating capital of $10 \%$ [38]. 


\section{Results and Discussion}

\subsection{Regression Results of Estimation on Costs and Outputs of Wheat and Maize Production}

The multicollinearity of explanatory variables was tested by a Condition Number Test before estimating models. The Condition Number Using Scaled Values of the explanatory variables (renting land, renting out land, head age, education, agricultural labor, block size, soil fertility, landform, Xifeng, Yuzhong, Mingle, and Huining) of both wheat (20.87) and maize (22.51) analyses were lower than 30, indicating there was no multicollinearity in regressions of Equation (1) and Equation (12) [48].

Equation (1) estimates the statistical association of rural households' farmland rental behaviors and input costs per unit output of wheat and maize production with least square method (OLS), and the results are provided in Tables 6 and 7, respectively. The results indicated that households renting land had significantly lower labor, chemical and total cost per unit output of wheat production, and significant lower labor, fertilizer, chemical and total cost per unit output of maize production, compared with those not renting land. However, they had significant higher machine cost per unit output in both of wheat and maize production, than those not renting land. On the other hand, households renting out land had significant higher land, machine, seed, fertilizer and total cost per unit output of wheat production, and significant higher land, labor, machine, seed and total cost per unit output of maize production, compared with those not renting land. Besides, they had significant lower output per mu in both of wheat and maize production.

Renting land had a significant negative correlation with labor cost per unit output of wheat $(-0.933)$ and maize $(-0.476)$ production, while significant positive correlation with machine cost per unit output of wheat (0.168) and maize (0.139) production (Tables 6 and 7). This indicated that households renting land inputted more money on machine to reduce labor cost, since their labor might be not enough for farming due to the enlarging of farm size. Besides, households renting land had significant lower chemical cost per unit output $(-0.022)$ of wheat production and significant lower fertilizer $(-0.082)$ and chemical $(-0.020)$ cost per unit output of maize production than those not renting land. A possible explanation is that households renting land tended to be specializing in farming, thus more reasonable amounts of fertilizers and chemicals were expected to be used by them. Although the association of renting land and output of wheat and maize per mu was non-significant, the negative coefficients implied a negative response of output to farm size, which was consistent with the study by Rada et al. [19]. The significant reduction of labor, fertilizer and chemical costs per unit output, and insignificant reduction of output per mu for households renting land resulted in a significant decrease in the total cost per unit output of wheat $(-0.827)$ and maize production $(-0.425)$. 
Table 6. Results of regressions on per unit output costs in wheat analysis.

\begin{tabular}{|c|c|c|c|c|c|c|c|c|c|}
\hline Coefficient (Robust SE) & Land Cost & Labor Cost & Machine Cost & Seed Cost & Water Cost & Fertilizer Cost & Chemical Cost & Total Cost & Output \\
\hline Renting land & $0.013(0.043)$ & $-0.933^{* * *}(0.274)$ & $0.168^{* * *}(0.057)$ & $0.015(0.020)$ & $-0.010(0.015)$ & $-0.050(0.031)$ & $-0.022 * *(0.009)$ & $-0.827^{* * *}(0.311)$ & $-5.256(12.659)$ \\
\hline Renting out land & $0.467^{* * *}(0.080)$ & $0.009(0.455)$ & $0.535^{* * *}(0.097)$ & $0.108^{* * *}(0.044)$ & $0.029(0.024)$ & $0.097^{* *}(0.046)$ & $-0.001(0.011)$ & $1.241 * *(0.572)$ & $-68.516^{* * *}(11.359)$ \\
\hline Head age & $-0.000(0.002)$ & $0.008(0.012)$ & $0.003(0.002)$ & $0.001(0.001)$ & $0.001 *(0.001)$ & $-0.001(0.001)$ & $0.001(0.000)$ & $0.012(0.014)$ & $-0.989 * *(0.412)$ \\
\hline Education & $0.002(0.007)$ & $-0.027(0.037)$ & $0.007(0.007)$ & $-0.001(0.002)$ & $0.000(0.002)$ & $-0.005(0.004)$ & $0.002(0.001)$ & $-0.022(0.046)$ & $-0.897(1.238)$ \\
\hline Agricultural labor & $0.041(0.073)$ & $0.569(0.496)$ & $0.067(0.086)$ & $0.028(0.028)$ & $-0.016(0.023)$ & $0.116 * *(0.054)$ & $0.034 *(0.019)$ & $0.862(0.563)$ & $-9.752(18.103)$ \\
\hline Block size & $-0.042 * *(0.020)$ & $-0.261^{* * *}(0.088)$ & $-0.008(0.020)$ & $0.001(0.004)$ & $-0.007 *(0.004)$ & $-0.019 *(0.011)$ & $-0.011^{* * *}(0.003)$ & $-0.342 * * *(0.103)$ & $1.972(3.938)$ \\
\hline Soil fertility & $0.024(0.034)$ & $-0.240(0.184)$ & $0.029(0.035)$ & $-0.017(0.016)$ & $-0.015 *(0.008)$ & $-0.044 *(0.025)$ & $0.014^{* *}(0.006)$ & $-0.251(0.211)$ & $17.017^{* *}(7.156)$ \\
\hline Landform & $0.039(0.081)$ & $-0.705(0.429)$ & $-0.551^{* * *}(0.098)$ & $-0.035(0.030)$ & $0.462 * * *(0.038)$ & $0.063(0.041)$ & $0.016(0.018)$ & $-0.704(0.532)$ & $154.913^{* * *}(20.836)$ \\
\hline Xifeng & $0.633^{* * *}(0.099)$ & $-1.992 * * *(0.657)$ & $0.413^{* * *}(0.111)$ & $-0.196^{* * *}(0.054)$ & $-0.001(0.016)$ & $0.021(0.077)$ & $-0.039 *(0.022)$ & $-1.223(0.761)$ & $22.083(21.165)$ \\
\hline Yuzhong & $0.164(0.124)$ & $-0.427(0.787)$ & $0.637^{* * *}(0.135)$ & $-0.112 *(0.060)$ & $-0.201^{* * *}(0.041)$ & $-0.175^{*}(0.090)$ & $-0.036(0.031)$ & $-0.199(0.956)$ & $-26.129(30.224)$ \\
\hline Mingle & $0.139(0.125)$ & $-2.528^{* * *}(0.754)$ & $0.582 * * *(0.136)$ & $-0.056(0.062)$ & $-0.283 * * *(0.039)$ & $-0.283^{* * *}(0.085)$ & $-0.103^{* * *}(0.029)$ & $-2.592 * * *(0.919)$ & $30.100(27.377)$ \\
\hline Huining & $0.129(0.123)$ & $-0.433(0.764)$ & $0.388^{* * *}(0.126)$ & $-0.062(0.061)$ & $0.024(0.015)$ & $-0.216^{* * *}(0.081)$ & $0.069^{* * *}(0.023)$ & $-0.297(0.923)$ & $-42.138^{* *}(21.247)$ \\
\hline Intercept & $0.598 * * *(0.127)$ & $4.717^{* * *}(0.825)$ & $0.007(0.135)$ & $0.259^{* * *}(0.079)$ & $-0.029(0.029)$ & $0.606^{* * *}(0.103)$ & $0.096^{* * *}(0.032)$ & $6.326^{* * *}(0.982)$ & $276.502 * * *(27.087)$ \\
\hline Observations & 322 & 322 & 322 & 322 & 322 & 322 & 322 & 322 & 322 \\
\hline Adjusted $R^{2}$ & 0.369 & 0.283 & 0.333 & 0.192 & 0.726 & 0.197 & 0.197 & 0.229 & 0.541 \\
\hline RMSE & 0.343 & 1.995 & 0.379 & 0.132 & 0.099 & 0.225 & 0.067 & 2.370 & 76.465 \\
\hline
\end{tabular}

Notes: ${ }^{*} * *$ and ${ }^{* * *}$ indicate statistical significance at $10 \%, 5 \%$ and $1 \%$ levels, respectively.

Table 7. Results of regressions on per unit output costs in maize analysis.

\begin{tabular}{|c|c|c|c|c|c|c|c|c|c|}
\hline Coefficient (Robust SE) & Land Cost & Labor Cost & Machine Cost & Seed Cost & Water Cost & Fertilizer Cost & Chemical Cost & Total Cost & Output \\
\hline Renting land & $-0.002(0.025)$ & $-0.476^{* * *}(0.111)$ & $0.139 * * *(0.025)$ & $0.011(0.011)$ & $-0.005(0.008)$ & $-0.082 * * *(0.020)$ & $-0.020 * * *(0.006)$ & $-0.425^{* * *}(0.137)$ & $-9.398(21.964)$ \\
\hline Renting out land & $0.247^{* * *}(0.045)$ & $0.393 * *(0.172)$ & $0.150 * * *(0.037)$ & $0.034 *(0.015)$ & $0.021(0.013)$ & $0.051(0.036)$ & $-0.006(0.011)$ & $0.901 * * *(0.240)$ & $-103.550^{* * *}(27.221)$ \\
\hline Head age & $-0.001(0.001)$ & $0.006(0.005)$ & $0.000(0.001)$ & $0.000(0.000)$ & $0.000(0.000)$ & $-0.002 *(0.001)$ & $0.000(0.000)$ & $0.004(0.006)$ & $-0.327(0.945)$ \\
\hline Education & $0.001(0.003)$ & $-0.007(0.016)$ & $0.003(0.002)$ & $0.002(0.001)$ & $-0.001(0.001)$ & $0.003(0.002)$ & $0.002 *(0.001)$ & $0.001(0.019)$ & $-1.588(2.740)$ \\
\hline Agricultural labor & $0.016(0.053)$ & $0.129(0.223)$ & $-0.053(0.039)$ & $-0.003(0.019)$ & $-0.010(0.022)$ & $0.034(0.031)$ & $-0.013(0.010)$ & $0.078(0.262)$ & 12.360 (38.001) \\
\hline Block size & $-0.016^{* *}(0.007)$ & $-0.012(0.035)$ & $0.008(0.006)$ & $0.000(0.002)$ & $-0.000(0.001)$ & $-0.000(0.005)$ & $-0.002 *(0.001)$ & $-0.022(0.040)$ & $-8.160(6.169)$ \\
\hline Soil fertility & $0.055^{* * *}(0.019)$ & $0.269^{* * *}(0.088)$ & $-0.012(0.013)$ & $0.007(0.007)$ & $0.005(0.006)$ & $0.021(0.015)$ & $0.012^{* * *}(0.004)$ & $0.355^{* * *}(0.112)$ & $-2.176(16.202)$ \\
\hline Landform & $0.191 * * *(0.030)$ & $-0.488^{* * *}(0.151)$ & $-0.011(0.018)$ & $-0.001(0.012)$ & $0.191^{* * *}(0.011)$ & $-0.006(0.020)$ & $0.002(0.007)$ & $-0.120(0.181)$ & $99.302 * * *(29.049)$ \\
\hline Xifeng & $0.336 * * *(0.030)$ & $-0.556^{* * *}(0.169)$ & $0.095^{* * *}(0.024)$ & $-0.013(0.011)$ & $-0.015^{* * *}(0.005)$ & $0.077 * * *(0.023)$ & $-0.019^{* * *}(0.007)$ & $-0.096(0.200)$ & $36.042(28.784)$ \\
\hline Yuzhong & $0.229 * * *(0.037)$ & $0.610^{* * *}(0.169)$ & $0.033 *(0.019)$ & $0.077 * * *(0.016)$ & $-0.026 *(0.013)$ & $0.098 * * *(0.027)$ & $0.035^{* * *}(0.009)$ & $1.151^{* * *}(0.205)$ & $-79.734^{* * *}(29.721)$ \\
\hline Mingle & $0.274^{* * *}(0.033)$ & $-0.361 * *(0.142)$ & $0.133^{* * *}(0.035)$ & $-0.014(0.015)$ & $-0.054^{* * *}(0.015)$ & $0.064^{* * *}(0.024)$ & $-0.021^{* * *}(0.007)$ & $0.014(0.169)$ & $-112.630^{* * *}(29.611)$ \\
\hline Intercept & $0.207 * * *(0.067)$ & $1.649 * * *(0.306)$ & $0.048(0.051)$ & $0.078^{* *}(0.032)$ & $0.016(0.021)$ & $0.250^{* * *}(0.059)$ & $0.057^{* * *}(0.016)$ & $2.317^{* * *}(0.370)$ & $610.606^{* * *}(64.266)$ \\
\hline Observations & 321 & 321 & 321 & 321 & 321 & 321 & 321 & 321 & 321 \\
\hline Adjusted $R^{2}$ & 0.546 & 0.207 & 0.262 & 0.164 & 0.657 & 0.126 & 0.226 & 0.261 & 0.074 \\
\hline RMSE & 0.189 & 0.875 & 0.145 & 0.078 & 0.064 & 0.153 & 0.044 & 1.077 & 161.920 \\
\hline
\end{tabular}

Notes: ${ }^{*}, * *$ and $* * *$ indicate statistical significance at $10 \%, 5 \%$ and $1 \%$ levels, respectively; only three dummies (Xifeng, Yuzhong, and Mingle) are included in maize analysis, since there is

no household growing maize in Ming county. 
Households renting out land had a much lower output of wheat (-68.516) and maize (-103.550) per mu than those not renting land, and this resulted in the significantly higher land (0.467), machine (0.535), seed (0.108), fertilizer (0.097) and total (1.241) costs per unit output of wheat production, and the significantly higher land (0.247), labor (0.393), machine (0.150), seed (0.034) and total (0.901) costs per unit output of maize production. A possible explanation is that, households renting out land often devoted plenty of time and effort to off-farm working, and gave less attention to framing, thus a dramatic reduction in wheat and maize outputs was found among them. The inefficient use of farmland among rural households renting out land was also revealed by a significant increase of land cost per unit output of wheat and maize production. During the survey, we found that households renting out land also used large amounts of machines to replace farming labor, since the increase of income and decrease of farming labor due to their off-farm working spurred them to use more agricultural machines. For example, for wheat production, the labor cost per mu of households renting land, not renting land and renting out land was 505.70 Yuan, 730.12 Yuan and 402.97 Yuan, respectively, while the machine cost per mu of households renting land, not renting land and renting out land was 129.83 Yuan, 119.98 Yuan and 191.67 Yuan, respectively. For maize production, the labor cost per mu of households renting land, not renting land and renting out land was 650.20 Yuan, 993.12 Yuan and 943.47 Yuan, respectively, while the machine cost per mu of households renting land, not renting land and renting out land was 139.00 Yuan, 61.66 Yuan and 128.66 Yuan, respectively. However, there was no significant reduction found in labor cost per unit output of wheat and maize production of these households, and this was mainly attributed to the reduction of outputs.

Overall, households renting land significantly reduced their cost per unit output by replacing farming labor with machine, while households renting out land significantly increased their cost per unit output due to the large reduction of outputs.

\subsection{Results of Cost Frontier Function and Cost Efficiency Estimation}

\subsubsection{Regression Results of Cost Frontier Function and Cost Inefficiency Estimation}

According to the method of estimating inefficiency components by Coelli and Battese [47], the cost frontier function and linear function for cost inefficiency components in Equation (12) were estimated by the maximum likelihood estimation (MLE) technique. Parameter estimates of the stochastic cost frontier function and cost inefficiency components were presented in Table 8. The resulting LR test statistics of the models for wheat and maize analysis were respectively 76.157 and 269.416 , which greatly exceeded the $1 \%$ critical value (8.273). Thus, the null hypothesis of no inefficiency effects was strongly rejected. The estimates for the variance parameter $(\gamma)$ were significant at $1 \%$ level in wheat (0.925) and maize (0.616) analysis, respectively. The value of $\gamma$ is the ratio of $\sigma_{u}^{2}$ to $\sigma^{2}$, therefore, the inefficiency effects were likely to be highly significant in the analysis on the costs of wheat and maize famers.

All the first-order coefficients of outputs and prices of inputs had the expected signs, indicating the positive partial cost elasticities at the sample mean (Table 8). In terms of the magnitude of these elasticities at the sample mean, the most important factors were the prices of labor and materials. The estimated coefficients for the price of land in the models of wheat and maize were small and not significant, suggesting the price of land had little correlation with the frontier costs of wheat and maize production. The estimated coefficients for prices of labor and materials were significant and respectively 0.459 and 0.504 in wheat analysis, 0.318 and 0.565 in maize analysis. The significant coefficients of labor and materials price, and insignificant coefficient of land price, might be because the quantities and costs of labor and materials were more variable than those of land to produce certain quantities of wheat and maize. 
Table 8. Results of regressions on cost frontier and cost inefficiency of wheat and maize production.

\begin{tabular}{|c|c|c|c|c|}
\hline \multirow{2}{*}{ Variable } & \multicolumn{2}{|c|}{ Wheat Analysis } & \multicolumn{2}{|c|}{ Maize Analysis } \\
\hline & Coefficient & Standard Error & Coefficient & Standard Error \\
\hline \multicolumn{5}{|c|}{ Stochastic cost frontier function } \\
\hline $\ln$ (Output) & $0.603 * * *$ & 0.018 & $0.739 * * *$ & 0.028 \\
\hline $\ln$ (Price of land) & 0.037 & 0.027 & 0.117 & 0.602 \\
\hline $\ln$ (Price of labor) & $0.459 * * *$ & 0.060 & $0.318^{* *}$ & 0.151 \\
\hline $\ln$ (Price of materials) & $0.504^{* * *}$ & 0.025 & $0.565^{* * *}$ & 0.146 \\
\hline Intercept & $1.693^{* * *}$ & 0.294 & 0.633 & 0.991 \\
\hline \multicolumn{5}{|c|}{ Cost inefficiency components } \\
\hline Renting land & $-1.826 *$ & 0.937 & $-1.100 *$ & 0.631 \\
\hline Renting out land & $0.775^{* *}$ & 0.352 & $0.482 * *$ & 0.208 \\
\hline Head age & $0.007 *$ & 0.004 & 0.004 & 0.010 \\
\hline Education & $-0.064^{* *}$ & 0.029 & -0.013 & 0.026 \\
\hline Agricultural labor & $1.540 * *$ & 0.651 & 0.118 & 0.366 \\
\hline Block size & $-0.254 *$ & 0.152 & $-0.127^{* *}$ & 0.064 \\
\hline Soil fertility & $-0.216^{*}$ & 0.125 & $-0.309 *$ & 0.177 \\
\hline Landform & $-0.622 * *$ & 0.262 & -0.131 & 0.287 \\
\hline Xifeng & 0.644 & 0.426 & -0.544 & 0.471 \\
\hline Yuzhong & $1.076^{* *}$ & 0.495 & $1.002^{* * *}$ & 0.281 \\
\hline Mingle & 0.667 & 0.492 & 0.192 & 0.544 \\
\hline Huining & $0.855^{* *}$ & 0.404 & - - & - - \\
\hline Intercept & $-2.014 * *$ & 0.971 & -1.566 & 0.726 \\
\hline$\sigma^{2}$ & $0.379 * * *$ & 0.138 & $0.188^{* * *}$ & 0.046 \\
\hline$\gamma$ & $0.925^{* * *}$ & 0.024 & $0.616^{* * *}$ & 0.112 \\
\hline Number of observations & 322 & & 321 & \\
\hline Log likelihood function & 15.731 & & -75.188 & \\
\hline LR test of the one-sided error & 76.157 & & 269.416 & \\
\hline
\end{tabular}

Notes: ${ }^{*}, * *$ and ${ }^{* * *}$ indicate statistical significance at $10 \%, 5 \%$ and $1 \%$ levels, respectively; - - indicates not applicable; only three dummies (Xifeng, Yuzhong, and Mingle) are included in maize analysis, since there is no household growing maize in Ming county.

The regression results of inefficiency models for wheat and maize analysis were presented in the middle part of Table 8 . The coefficients of renting land were significant and negative in the wheat $(-1.826)$ and maize $(-1.100)$ analyses, while the coefficients of renting out land were significant and positive in the wheat (0.775) and maize (0.482) analyses. This indicated that households renting land tended to have smaller cost inefficiency components, while those renting out land tended to have larger cost inefficiency components, compared with those without renting land. Combined with the regression results of costs per unit output, the primary cause was that households renting land improved their cost efficiency mainly by replacing labor with machine and rational utilization of fertilizers and chemicals, while households renting out land reduced their cost efficiency due to the dramatic reduction in outputs.

Besides, some other characteristics of farmers and farmland also significantly correlated with the cost inefficiency components of wheat and maize production (Table 8). Head age and education respectively had significantly positive and negative correlation with cost inefficiency components of wheat production, indicating households with young and high education level heads had higher cost efficiency in wheat production than those with old and low education level heads. A possible explanation is that, young household heads might be more active, energetic and easier to accept new technologies of farming compared with those with very high age, and household heads with high education level were more knowledgeable on reasonable use of machine, fertilizers and chemicals than those with low education level. Another important source of cost inefficiency was the surplus of agricultural labor force. Agricultural labor was significantly and positively related to the cost inefficiency components of wheat production, suggesting wheat farmers with high agricultural labor ratio had lower cost efficiency than those with low agricultural labor ratio. The negative correlation of agricultural labor ratio and cost efficiency could mainly ascribe to the widely surplus of the agricultural 
labor force in study regions. The average block size and soil fertility had significant negative correlation with cost inefficiency components in both wheat and maize production, and landform had significant negative correlation with cost inefficiency components of maize production, suggesting high quality farmlands can greatly reduce agricultural production costs.

\subsubsection{Cost Efficiency}

After estimating the stochastic frontier cost function and cost inefficiency components, cost efficiency for each wheat and maize farm households was also calculated. Figure 2 reports the kernel density distribution of cost efficiency of wheat and maize production in the study area. Figure 2 illustrates the variations in cost efficiency across households, revealing that the largest density of wheat farmers fell into the $0.7-1.0$ range of cost efficiency, and the largest density of maize farmers fell into the $0.8-1.0$ range of cost efficiency, but a small peak emerged around 0.65 . In other words, a large share of wheat and maize farmers were costly efficient.

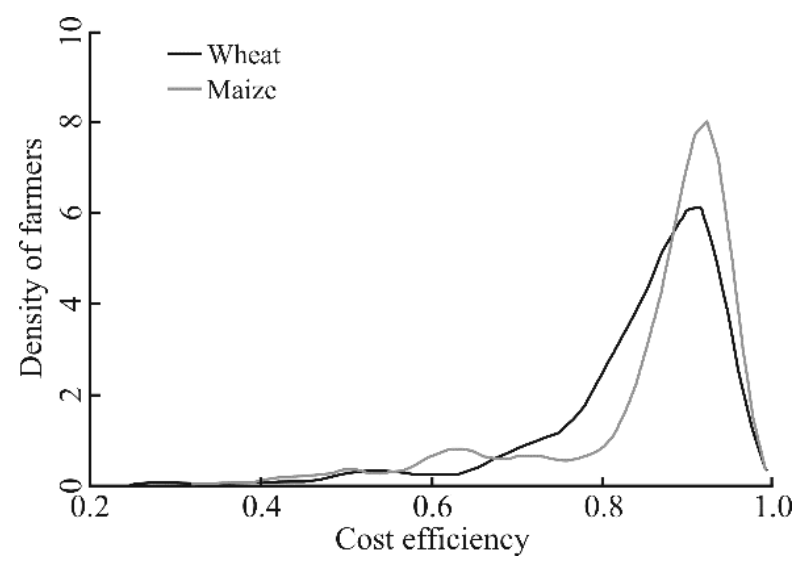

Figure 2. Distribution of cost efficiency for wheat and maize production.

Figure 3 shows the distribution of cost efficiency of wheat and maize farmer groups depending on farmland rental status (Figure 3A,B), including renting land, not renting land and renting out land, and depending on planted area size of wheat and maize (Figure $3 C, D$ ), including large size (planted area $\geq 5.0 \mathrm{mu}$ ), medium size $(0.25 \mathrm{mu} \leq$ planted area $<5.0 \mathrm{mu})$ and small size (planted area $<2.5 \mathrm{mu}$ ). The results of cost efficiency distribution of household groups depending on farmland rental status (Figure $3 \mathrm{~A}, \mathrm{~B})$ indicated that a large share of wheat farmers renting land $(70.00 \%)$ had a cost efficiency score in the range of 0.9-1.0, which was larger than that of farmers not renting land $(28.94 \%)$ and renting out land (21.62\%). In addition, a large share of maize farmers renting land (85.42\%) had a cost efficiency score in the range of $0.9-1.0$, which was larger than that of farmers not renting land $(46.38 \%)$ and renting out land $(13.16 \%)$.

For the distribution of cost efficiency of household groups depending on planted area size (Figure 3C,D), a large share of wheat farmers with large size $(84.78 \%$ ) had a cost efficiency score in the range of $0.8-1.0$, which was larger than that of farmers with medium size (75.68\%) and small size $(73.11 \%)$. Similarly, a large share of maize farmers with large size $(90.19 \%)$ had a cost efficiency score in the range of $0.8-1.0$, which was larger than that of farmers with medium $(80.34 \%)$ and small size $(67.64 \%)$. 

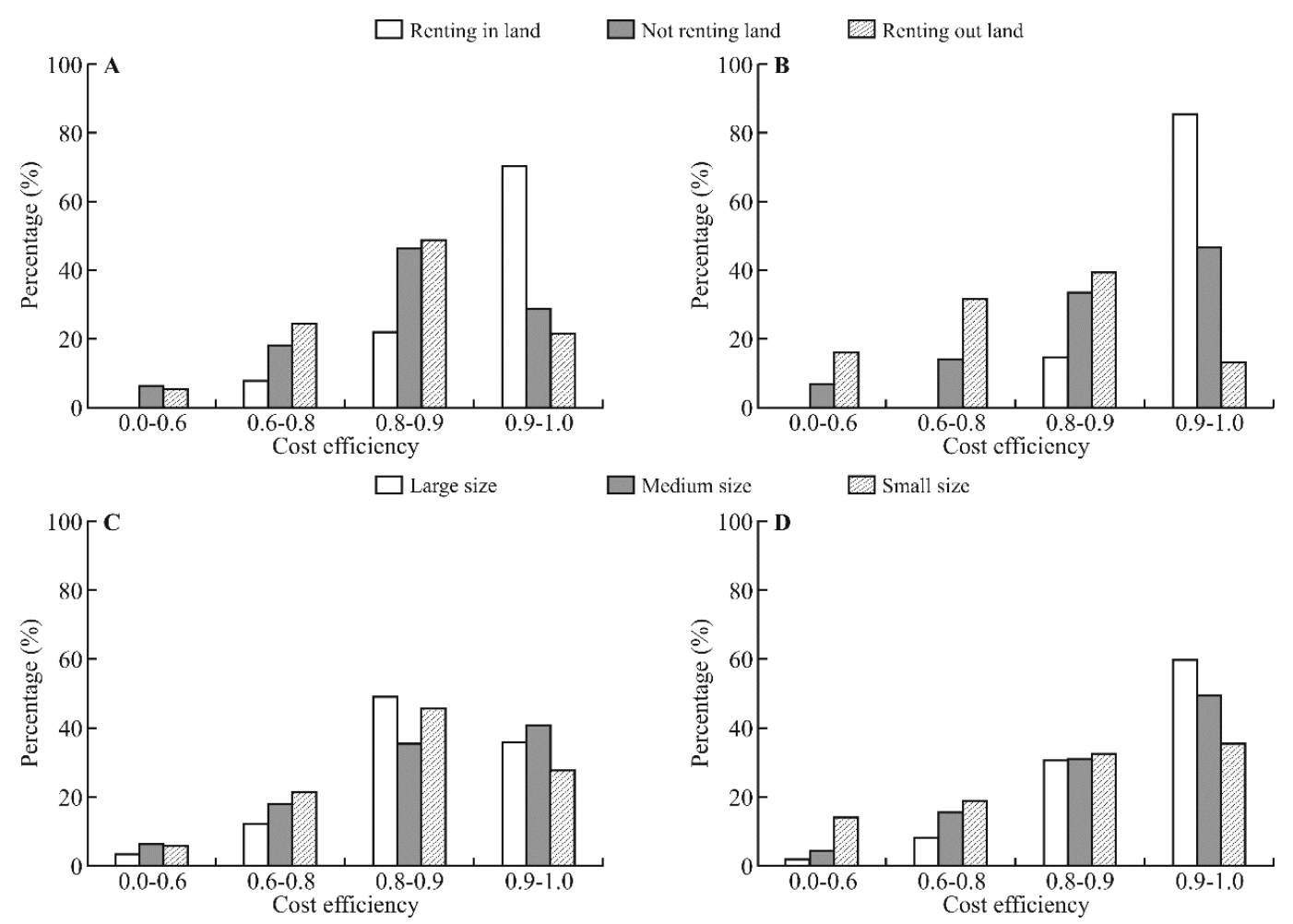

Figure 3. Distribution of cost efficiency of rural household groups depending on farmland rental status: (A) for wheat production; and (B) for maize production, and planted area size: (C) for wheat production; and (D) for maize production.

A multiple comparison was also taken to compare the means of cost efficiency of households groups depending on farmland rental status and planted area size of each crop. Figure 4 presents the cost efficiency of different household groups depending on farmland rental status (Figure 4A) and planted area size (Figure 4B). As expected, wheat famers renting land had higher mean of cost efficiency (0.905) than those of not renting land (0.830) and renting out land (0.813); maize farmers renting land also had higher mean of cost efficiency (0.934) than those of not renting land (0.846) and renting out land (0.753). Similar results were also found for household groups depending on planted area size: wheat farmers with large size had higher mean of cost efficiency $(0.856)$ than those with medium size (0.839) and small size (0.828); and maize farmers with large size also had higher mean of cost efficiency (0.888) than those with medium size (0.856) and small size $(0.800)$.
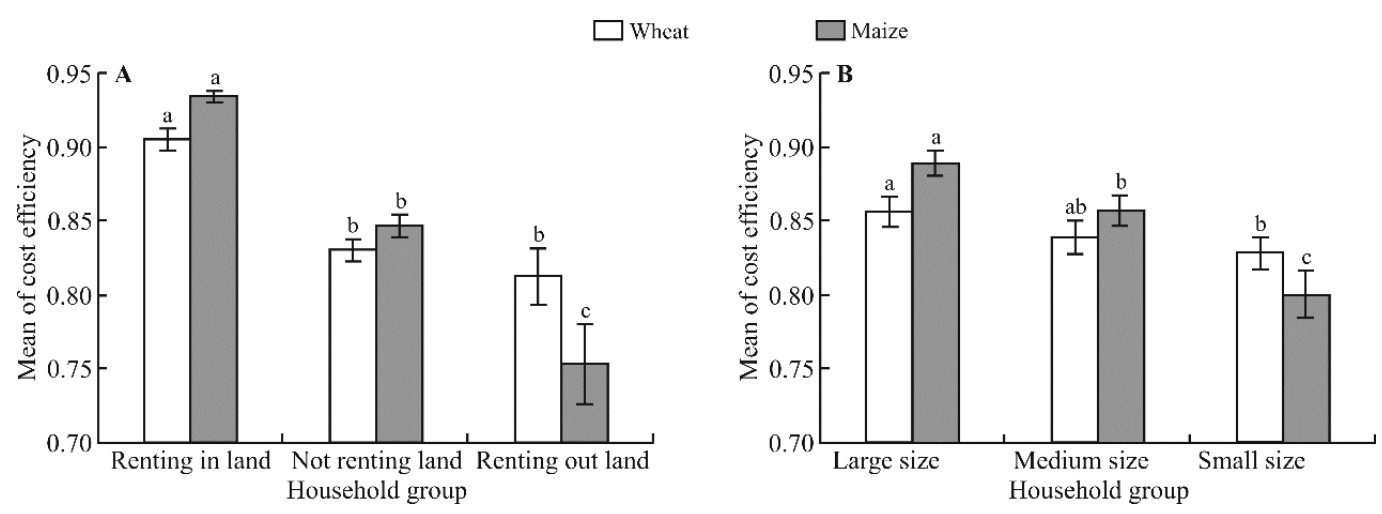

Figure 4. Cost efficiency of different household groups depending on: farmland rental status (A); and planted area size (B). Different letters indicate significant difference at 0.10 level for each crop. 
Although the differences among different groups depending on farmland rental status had the same tendency as those among groups depending on planted area size, the former had larger gaps. This might be because farmland rental had more positive effects on cost efficiency by transferring farmland to master farming hands than those gained from scale effects in the study area. In addition, only $15.53 \%$ and $14.95 \%$ of households rented land in the wheat and maize analyses, indicating that only a small part share of large scale farm came from farmland rental.

\section{Conclusions}

Due to the booming of farmland rental markets in China, debates over farmland rental are ongoing, especially its correlation with agricultural productivity [18]. An in-depth understanding on the statistical association of rural households' farmland rental behaviors and their input use on farmland, as well as cost efficiency of agricultural production could help policy makers introduce more targeted rural development policies. Based on survey data of 419 wheat and maize farmers in 25 villages in five counties of Gansu Province, this paper used linear regression models and stochastic frontier models to estimate the differences in inputs and outputs of wheat and maize production among households with different farmland rental behaviors, and the consequent impacts on the differences in cost efficiency.

The results indicated that households renting land reduced their input cost on farmland by replacing labor with machines and using less fertilizer, and without decreasing wheat and maize outputs by much. These caused a significant increase in cost efficiency of them. On the other hand, households renting out land had significant lower outputs per mu of wheat and maize than those not renting land, even though they also experienced the same process (replacing labor with machines) with households renting land. This caused a significant production efficiency loss for these households. The results also showed a significant negative association of rural households' land renting behavior and costs of fertilizer and chemicals, and they shed new light on the sustainability of agricultural production. In addition, the results of cost efficiency distribution of household groups depending on farmland rental status and planted crop area size also showed the highest cost efficiency achieved by farmers renting land or with large planted crop area size, the medium cost efficiency achieved by farmers not renting land or with medium planted crop area size, and the lowest cost efficiency achieved by farmers renting out land or with small planted crop size. Thus, farmland rental indeed improved agricultural productivity by transferring land from farmers with low productivity to farmers more specializing on farming.

The findings here suggested that farmland rental and consolidation in China are beneficial to agricultural productivity and environmental protection. However, the means of cost efficiency of wheat $(0.848)$ and maize $(0.840)$ production indicated that there is still room for improvement under current production methods and technologies. Besides, with the further development of farmland rental and off-farm employments, using machines to replace labor will become increasingly important to China. Machinery purchase subsidization has been widely implemented in China, and it has achieved satisfactory results. China's experience offers a new perspective for other developing countries.

Our results were based on data from a single year, and this should be a limitation to understand the changes of impacts of farmland rental on input use and cost efficiency with years, but these results still provide important references for policy makers. Furthermore, this study only tested the statistical association of farmland rental cost efficiency. From the farmers' perspective, how to increase income is the top issue, and this may also be the reason of some households renting out all of their farmland and quitting farming totally while some households enlarging their farm size by renting some land. Thus, impacts of farmland rental and consolidation on farmers' income and income inequality should be estimated in future.

Acknowledgments: This work was funded by the Chinese Center for Strategic Research of Grassland Agriculture Development (SRGAD). 
Author Contributions: Ying Liu calculated and analyzed the data, and wrote the paper. Zhibiao Nan designed the research project. Chenggang Wang and Zeng Tang gave suggestions for the whole study.

Conflicts of Interest: The authors declare no conflict of interest.

\section{References}

1. Godfray, H.C.J.; Beddington, J.R.; Crute, I.R.; Haddad, L.; Lawrence, D.; Muir, J.F.; Pretty, J.; Robinson, S.; Thomas, S.M.; Toulmin, C. Food security: The challenge of feeding 9 billion people. Science 2010, 327, 812-818. [CrossRef] [PubMed]

2. Myers, S.S.; Smith, M.R.; Guth, S.; Golden, C.D.; Vaitla, B.; Mueller, N.D.; Dangour, A.D.; Huybers, P. Climate change and global food systems: Potential impacts on food security and undernutrition. Annu. Rev. Public Health 2017, 38, 259-277. [CrossRef] [PubMed]

3. Gilbert, N.; Gewin, V.; Tollefson, J.; Sachs, J.; Potrykus, I. How to feed a hungry world. Nature 2010, 466, 531-532.

4. Wang, X.L.; Chen, Y.Q.; Sui, P.; Yan, P.; Yang, X.L.; Gao, W.S. Preliminary analysis on economic and environmental consequences of grain production on different farm sizes in North China Plain. Agric. Syst. 2017, 153, 181-189. [CrossRef]

5. Hubacek, K.; Guan, D.B.; Barua, A. Changing lifestyles and consumption patterns in developing countries: A scenario analysis for China and India. Futures 2007, 39, 1084-1096. [CrossRef]

6. Wang, Y.B.; Wu, P.T.; Engel, B.A.; Sun, S.K. Comparison of volumetric and stress-weighted water footprint of grain products in China. Ecol. Indic. 2015, 48, 324-333. [CrossRef]

7. Zhang, F.S.; Cui, Z.L.; Fan, M.S.; Zhang, W.F.; Chen, W.P.; Jiang, R.F. Integrated soil-crop system management: Reducing environmental risk while increasing crop productivity and improving nutrient use efficiency in China. J. Environ. Qual. 2010, 40, 1051-1057. [CrossRef] [PubMed]

8. Jiao, X.Q.; Lyu, Y.; Wu, X.B.; Li, H.G.; Cheng, L.Y.; Zhang, C.C.; Yuan, L.X.; Jiang, R.F.; Jiang, B.W.; Rengel, Z.; et al. Grain production versus resource and environmental costs: Towards increasing sustainability of nutrient use in China. J. Exp. Bot. 2016, 67, 4935-4949. [CrossRef] [PubMed]

9. Zhang, F.Q. Retreat from equality or advance towards efficiency? Land markets and inequality in rural Zhejiang. China Q. 2008, 195, 535-557. [CrossRef]

10. Zhang, F.S.; Chen, X.P.; Vitousek, P. Chinese agriculture: An experiment for the world. Nature 2013, 497, 33-35. [CrossRef] [PubMed]

11. Lin, J.Y. Rural reforms and agricultural growth in China. Am. Econ. Rev. 1992, 28, 34-51.

12. Feng, S.Y. Land rental, off-farm employment and technical efficiency of farm households in Jiangxi province, China. NJAS 2008, 55, 363-378. [CrossRef]

13. Tilman, D.; Cassman, K.G.; Matson, P.A.; Naylor, R.; Polasky, S. Agricultural sustainability and intensive production practices. Nature 2002, 418, 671-677. [CrossRef] [PubMed]

14. Guo, J.H.; Liu, X.J.; Zhang, Y.; Shen, J.L.; Han, W.X.; Zhang, W.F.; Christie, P.; Goulding, K.W.T.; Vitousek, P.M.; Zhang, F.S. Significant acidification in major Chinese croplands. Science 2010, 327, 1008-1010. [CrossRef] [PubMed]

15. Chen, X.P.; Cui, Z.L.; Fan, M.S.; Vitousek, P.; Zhao, M.; Ma, W.Q.; Wang, Z.L.; Zhang, W.J.; Yan, X.Y.; Yang, J.C.; et al. Producing more grain with lower environmental costs. Nature 2014, 514, 486-489. [CrossRef] [PubMed]

16. Deininger, K.; Jin, S.Q.; Xia, F.; Huang, J.K. Moving off the farm: Land institutions to facilitate structural transformation and agricultural productivity. World Dev. 2013, 59, 505-520. [CrossRef]

17. Wang, J.Y.; Chen, K.Z.; Gupta, S.D.; Huang, Z.H. Is small still beautiful? A comparative study of rice farm size and productivity in China and India. China Agric. Econ. Rev. 2015, 7, 484-509. [CrossRef]

18. Zuo, Y.H.; Ma, L.; Cai, H.L.; Wu, T.L.; Xin, X. China's on-going debates over large-scale farming: What are the pros and cons? China Agric. Econ. Rev. 2015, 7, 338-343. [CrossRef]

19. Rada, N.; Wang, C.G.; Qin, L.J. Subsidy or market reform? Rethinking China's farm consolidation strategy. Food Policy 2015, 57, 93-103. [CrossRef]

20. Ma, X.L.; Heerink, N.; Lerland, E.V.; Berg, M.V.D.B.; Shi, X.P. Land tenure security and land investments in Northwest China. China Agric. Econ. Rev. 2013, 5, 281-307. [CrossRef]

21. Feng, S.Y.; Heerink, N.; Ruben, R.; Qu, F.T. Land rental market, off-farm employment and agricultural production in Southeast China: A plot-level case study. China Econ. Rev. 2010, 21, 598-606. [CrossRef] 
22. Huang, J.K.; Gao, L.L.; Rozelle, S. The effect of off-farm employment on the decisions of households to rent out and rent in cultivated land in China. China Agric. Econ. Rev. 2012, 4, 5-17. [CrossRef]

23. Ito, J.; Bao, Z.S.; Ni, J. Land rental development via institutional innovation in rural Jiangsu, China. Food Policy 2016, 59, 1-11. [CrossRef]

24. Cheng, X.H. Effectively strengthen the management and services in farmland transfer. Manag. Admin. Rural Cooper. 2009, 1, 6-11. (In Chinese)

25. Ministry of Agriculture of the People's Republic of China. Reply to the Suggestion Number 1392 in Fourth Meeting of the 12th National People's Congress (NPC). 2016. Available online: http:/ /www.moa.gov.cn/ zwllm/tzgg/tz/201608/t20160822_5249449.htm (accessed on 12 August 2017).

26. Kung, J.K. Off-farm labor markets and the emergence of land rental markets in rural China. J. Compar. Econ. 2002, 30, 395-414. [CrossRef]

27. Che, Y. Off-farm employments and land rental behavior: Evidence from rural China. China Agric. Econ. Rev. 2016, 8, 37-54. [CrossRef]

28. Deininger, K.; Jin, S.Q. Land sales and rental markets in transition: Evidence from rural Vietnam. Oxf. Bull. Econ. Stat. 2008, 70, 67-101.

29. Yan, X.H.; Huo, X.X. Drivers of household entry and intensity in land rental market in rural China: Evidence from North Henan province. China Agric. Econ. Rev. 2016, 8, 345-364. [CrossRef]

30. Yao, Y. The development of the land lease market in rural China. Land Econ. 2000, 76, 252-266. [CrossRef]

31. Pender, J.; Fafchamps, M. Land lease markets and agricultural efficiency in Ethiopia. J. Afr. Econ. 2005, 15, 251-284. [CrossRef]

32. Jin, S.Q.; Deininger, K. Land rental markets in the process of rural structural transformation: Productivity and equity impacts from China. J. Compar. Econ. 2009, 37, 629-646. [CrossRef]

33. Gao, L.L.; Huang, J.K.; Rozelle, S. Rental markets for cultivated land and agricultural investments in China. Agric. Econ. 2012, 43, 391-403. [CrossRef]

34. Deininger, K. Land markets in developing and transition economies: Impact of liberalization and implications for future reform. Am. J. Agric. Econ. 2003, 85, 1217-1222. [CrossRef]

35. Lohmar, B.; Zhang, Z.X.; Somwaru, A. Land rental market development and agricultural production in China. In Proceedings of the Annual Meetings of the American Agricultural Economics Association, Chicago, IL, USA, 5-8 August 2001.

36. Wang, Y.H.; Xin, L.J.; Li, X.B.; Yan, J.Z. Impact of land use rights transfer on household labor productivity: A study applying propensity score matching in Chongqing, China. Sustainability 2017, 9, 4. [CrossRef]

37. Fan, S.G. Effects of technological change and institutional reform on production growth in Chinese agriculture. Am. J. Agric. Econ. 1991, 73, 266-275. [CrossRef]

38. Bravo-Ureta, B.E.; Evenson, R.E. Efficiency in agricultural production: The case of peasant farmers in eastern Paraguay. Agric. Econ. 1994, 10, 27-37. [CrossRef]

39. Koirala, K.H.; Mishra, A.; Mohanty, S. Impact of land ownership on productivity and efficiency of rice farmers: The case of the Philipines. Land Use Policy 2016, 50, 371-378. [CrossRef]

40. National Bureau of Statistics of the People's Republic of China. A Statement of Grain Yield in 2015 from National Bureau of Statistics of the People's Republic of China. 2015. Available online: http:/ /www.stats. gov.cn/tjsj/zxfb /201512/t20151208_1286449.html (accessed on 12 August 2017).

41. Wang, X. Around five million mu of contracted farmland in rural Gansu province, China. Gansu Daily, 3 September 2012. (In Chinese)

42. Wang, C. Let famers assured to transfer farmland. Ren Min Zheng Xie Bao, 1 September 2014. (In Chinese)

43. Fabozzi, F.J. The Handbook of Mortgage-Backed Securities, 7th ed.; Oxford University Press: Oxford, UK, 2016; pp. 3-29, ISBN 978-0-19-878577-4.

44. Coelli, T.J.; Rao, D.S.P.; O'Donnell, C.J.; Battese, G.E. An Introduction to Efficiency and Productivity Analysis, 2nd ed.; Springer: New York, NY, USA, 2005; pp. 241-288, ISBN 978-1-4615-5493-6.

45. Cobb, W.C.; Douglas, P.H. A theory of production. Am. Econ. Rev. 1928, 18, 139-165.

46. Kopp, R.J.; Smith, V.K. Frontier production function estimates for steam electric generation: A comparative analysis. South. Econ. J. 1980, 47, 1049-1059. [CrossRef] 
47. Battese, G.E.; Coelli, T.J. A model for technical inefficiency effects in a stochastic frontier production function for panel data. Empir. Econ. 1995, 20, 325-332. [CrossRef]

48. Goldstein, R. Conditioning diagnostics: Collinearity and weak data in regression. Technometrics 1993, 35, 85-86. [CrossRef]

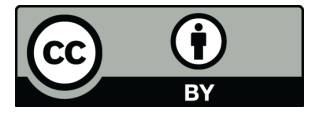

(c) 2017 by the authors. Licensee MDPI, Basel, Switzerland. This article is an open access article distributed under the terms and conditions of the Creative Commons Attribution (CC BY) license (http:/ / creativecommons.org/licenses/by/4.0/). 